\title{
A bélflóra patofiziológai jelentősége és szerepe mint terápiás célpont májbetegségekben
}

\author{
Hagymási Krisztina dr. ${ }^{1 *}$ - Bacsárdi Anna oh. ${ }^{2 *}$. Egresi Anna dr. ${ }^{1}$ \\ Berta Evelin oh. ${ }^{2}$. Tulassay Zsolt dr. ${ }^{1}$. Lengyel Gabriella dr. ${ }^{1}$ \\ ${ }^{1}$ Semmelweis Egyetem, Általános Orvostudományi Kar, II. Belgyógyászati Klinika, Budapest \\ ${ }^{2}$ Semmelweis Egyetem, Általános Orvostudományi Kar, Budapest
}

\begin{abstract}
A bélben jelen lévő mikroorganizmusok összessége, azaz a bélflóra szimbiózisban él a gazdaszervezettel, s jelentősen hozzájárul, ám ugyanakkor befolyásolja is annak homeosztázisát. Feltételezhető, hogy számos intestinalis és extraintestinalis kórkép patofiziológiájában központi szerepet tölt be, s meghatározhatja azok kialakulását, lefolyását, szövődményeit. Az intestinalis mikrobióta fontos érdeklódési és kutatási témává vált az elmúlt időben, különösen a hepatológiában, hiszen a máj az a szervünk, amely első szúroőként találkozik a bélből felszívódott tápanyagokkal, bakteriális alkotókkal, toxinokkal és metabolitokkal. A különböző májbetegségek, mint az alkoholos, a nem alkoholos zsírmáj, a steatohepatitis, a cirrhosis vagy a hepatocellularis carcinoma kialakulása összefüggésbe hozható a bélflóra megváltozott összetételével, illetve aktivitásával, így feltételezhető, hogy pre-, pro- és antibiotikumokkal történő befolyásolása a kórképek kezelésében szerephez juthat. Összefoglaló cikkükben a szerzők bemutatják a bélflóra kapcsolatát a különböző etiológiájú májbetegségekkel, valamint áttekintik a terápia lehetőségeit is.

Orv Hetil. 2018; 159(36): 1465-1474.
\end{abstract}

Kulcsszavak: mikrobióta, mikrobiom, bélpermeabilitás, májbetegségek, dysbiosis, rebiosis, probiotikumok, prebiotikumok

\section{The role of gut microbiota in chronic liver diseases, and treatment possibilities}

The community of microorganisms in the intestine, namely gut microbiome lives in symbiosis with the host, contributing to its homeostasis and influencing it simultaneously. It can be suspected that gut microbiome plays a central role in the pathophysiology of intestinal and extraintestinal diseases: determining their development, progress and complications. Recently, intestinal microbiome has become a highlighted field of interest and important topic in research, especially in hepatology. It is in the focus of relevant research as the liver is the organ which meets nutrients, bacterial components, toxins and metabolites at first, as a filter. The evolvement of different liver diseases - just like alcoholic and non-alcoholic fatty liver disease, steatohepatitis, cirrhosis or hepatocellular carcinoma - correlates with the changed composition and activity of gut microbiome. Thus, it can be hypothesized that pre-, pro- and antibiotics could have an impact on the treatment of these diseases. In our review article, the relationship between intestinal flora and liver diseases with different etiologies as well as therapeutic possibilities are discussed.

Keywords: microbiome, microbiota, gut permeability, liver diseases, dysbiosis, rebiosis, probiotics, prebiotics

Hagymási K, Bacsárdi A, Egresi A, Berta E, Tulassay Zs, Lengyel G. [The role of gut microbiota in chronic liver diseases, and treatment possibilities]. Orv Hetil. 2018; 159(36): 1465-1474.

(Beérkezett: 2018. április 28.; elfogadva: 2018. május 22.)

Semmelweis Ignác születésének 200. évfordulója évében a Szerkesztőség felkérésére készített tanulmány.

*A két szerző egyenlő arányban vett részt a közlemény elkészítésében. 


\section{Rövidítések}

$4 \mathrm{NQO}=4$-nitrokinolin-1-oxid; ACC $=$ acetil-koenzim-A-karboxiláz; $\mathrm{AH}=$ alkoholos hepatitis; $\mathrm{AIH}=$ autoimmun hepatitis; $\mathrm{ALD}=($ alcoholic liver disease $)$ alkoholos májbetegség; $\mathrm{BMI}=$ (body mass index) testtömegindex; CRP = C-reaktív protein; DAMP $=($ danger $/$ damage-associated molecular patterns $)$ veszélyasszociált molekuláris mintázat; DNS = dezoxiribonukleinsav; DPP4 = dipeptidil-peptidáz-4; DPPH = 1,1-difenil2-pikrilhidrazil; EEG = elektroencefalográfia; $\mathrm{FISH}=$ fluoreszcens in situ hibridizáció; FMT = (fecal microbial transplantation) széklet mikrobiális transzplantáció; FUT2 = fukozil-transzferáz-2; G6PD = glükóz-6-foszfát-dehidrogenáz; $\mathrm{GABA}=$ (gamma-aminobutyric acid) gamma-amino-vajsav; GGT = gamma-glutamil-transzferáz; GI = gastrointestinalis; $\mathrm{GLPl}=$ (glucagon-like peptide-1) glükagonszerü peptid-1; GOT = glutamát-oxálacetát-aminotranszferáz (= ASAT); GPT = glutamát-piruvát-aminotranszferáz (= ALAT); HBV = hepatitis B-vírus; $\mathrm{HCC}=$ hepatocellularis carcinoma; $\mathrm{HCV}=$ hepatitis C-vírus; $\mathrm{HE}=$ hepaticus encephalopathia; HSCs = (hepatic stellate cells) a máj csillagsejtjei; IBD $=($ inflammatory bowel disease) gyulladásos bélbetegség; IL = interleukin; $\mathrm{K}-\mathrm{PAG}=$ (kidney-type phosphate-activated glutaminase) vese típusú foszfátaktivált glutamináz; L-PAG = (liver-type phosphate-activated glutaminase) máj típusú foszfátaktivált glutamináz; LPS = lipopoliszacharid; MDR2 = multidrogrezisztencia-transzporter-2, P-glikoprotein; MUC2 = mucin-2 (gén); MyD88 = myeloid differentiation primary response $88 ; \mathrm{NAFLD}=$ (nonalcoholic fatty liver disease) nem alkoholos zsírmáj betegség; $\mathrm{NASH}=$ nem alkoholos steatohepatitis; $\mathrm{NF} \kappa \mathrm{B}=$ nukleáris faktor kappa-B; NKT = (natural killer T) természetes ölösejtek; $\mathrm{PAMP}=$ (pathogen associated molecular patterns $)$ patogénaszszociált molekuláris mintázat; $\mathrm{PBC}=$ primer biliaris cholangitis; PSC = primer szklerotizáló cholangitis; PYY = peptid YY; $\mathrm{qPCR}=$ (quantitative polymerase chain reaction) kvantitatív polimeráz-láncreakció; RCT $=$ (randomized controlled trial $)$ randomizált, kontrollált vizsgálat; REG3 = regenerating isletderived protein $3 ; \mathrm{REG} 3 \mathrm{~B}=$ regenerating islet-derived protein 3-beta; REG3G = regenerating islet-derived protein 3-gamma; $\mathrm{rRNS}=$ riboszomális ribonukleinsav; $\mathrm{SCFA}=$ (short-chain fatty acid) rövid szénláncú zsírsavak; sTNFR = szolúbilis tumornekrózisfaktor-receptor; TLR $=$ (Toll-like receptor $)$ Toll-szerű receptor; TNF $\alpha=$ tumornekrózisfaktor-alfa; VLDL $=$ (very-lowdensity lipoprotein) nagyon alacsony sürüségü lipoprotein

Gyomor-bél rendszerünket nagy számban kolonizálják a mikroorganizmusok $\left(4^{*} 10^{13} \mathrm{sejt}\right)[1]$. A bélmikrobiótát baktériumok (több mint 1000 baktériumfaj, a leggyakoribbak: Bacteroidetes, Firmicutes és Actinobacteria), vírusok, gombák és paraziták alkotják, amelyek a gastrointestinalis traktus nyálkahártyáján - a szájüregtől a vastagbélig - mindenütt megtalálhatók [2]. A mikroorganizmusok közössége (mikrobióta) a génjeikkel és genomjaikkal a bélmikrobiom [3]. Összetételét az életkor, a nem, az etnikum, a földrajzi helyzet, a genetikai háttér, az immunrendszer fejlődése és az étrend is befolyásolja $[4,5]$. A mikrobióta összetételének felbomlása a dysbiosis, amely az „egészség” és „betegség” közötti egyensúlyt megbonthatja [3].
Az egészséges bélflóra-gazdaszervezet szimbiózisa mindkét fél számára hasznos. A bél az itt kolonizáló baktériumoknak tápanyagban gazdag környezetet nyújt, táplálékforrást biztosítva növeli a metabolikusan aktív baktériumpopulációt. Ugyanakkor a bélflóra a gazdaszervezet számára esszenciális tápanyagokat biztosít (Bvitamin, K-vitamin), növeli azok biológiai hasznosulását, hozzájárul a nem emészthetô tápanyagok (étrendi rostok) emésztéséhez, továbbá az ezek lebontásából származó rövid szénláncú zsírsavak (butirát, propionátok, acetátok) energiaforrások. A mikrobiom fontos szerepet játszik a veleszületett és a szerzett immunrendszer kialakulásában és szabályozásában lokálisan a bélnyálkahártyában, valamint szisztémásan is [6-8].

Egyre több bizonyíték van arra, hogy a bélflóra szerepet játszik többek közt az elhízás, a nem alkoholos zsírmáj betegség/steatohepatitis, az alkohol okozta májbetegség, a primer szklerotizáló cholangitis, a cirrhosis és a hepatocellularis carcinoma kialakulásában. A különböző májbetegségek ugyanakkor a bélflóra összetételét, aktivitását befolyásolhatják (1. ábra) $[4,5]$.

Számos tanulmány utal arra, hogy ezen betegségek progressziója lassítható, szövődményeik kialakulása befolyásolható a bélflóra összetételének módosításával, probiotikumok és antibiotikum használatával.

\section{A bélflóráról általában}

A humán bélflóra körülbelül $1,5 \mathrm{~kg}$, megközelítőleg $10^{14}$ számú mikroorganizmust és közel 2000 különböző fajt tartalmaz, amelyek túlnyomó része anaerob [9]. Az emberi test minden olyan felületét benépesítik, amely a külső környezettel érintkezik.

Számos vizsgálat kimutatta egészséges egyének bélflórájának sokféleségét (diverzitását). A bélflóra minőségi és mennyiségi szempontból jellemző az egyénre, de azt az életkor, valamint az étrendi és környezeti hatások is meghatározzák [10].

A mikroflóra összetétele a gyomor-bél rendszerben distalis irányban is változik. A gyomorban, a duodenumban és a jejunumban kis mennyiségben vannak jelen a mikroorganizmusok; ezek föként oropharyngealis eredetü, aerob, Gram-pozitív baktériumok (Lactobacillus, Enterococcus). Az ileumban a béltartalom grammjában $10^{5}-10^{9}$ körüli a baktériumszám, amelyek nagy része coliform baktérium. Az iliocoecalis billentyú után viszont nő a baktériumkoncentráció $\left(10^{9}-10^{12}\right)$, fó alkotói a Bacteroides, a bifidobaktérium, a Clostridium és a Lactobacillus fajok [10].

Egy magzat gastrointestinalis traktusa fiziológiásan steril. A születés során, valamint közvetlenül azt követően az anyai flórából és a környezetből származó baktériumok kolonizálják az újszülött bélrendszerét, elsőként a fakultatív aerobok, majd az anaerobok. A mikroflóra 12-24 hónapos korban sok hasonlóságot mutat a felnóttekével [9]. 


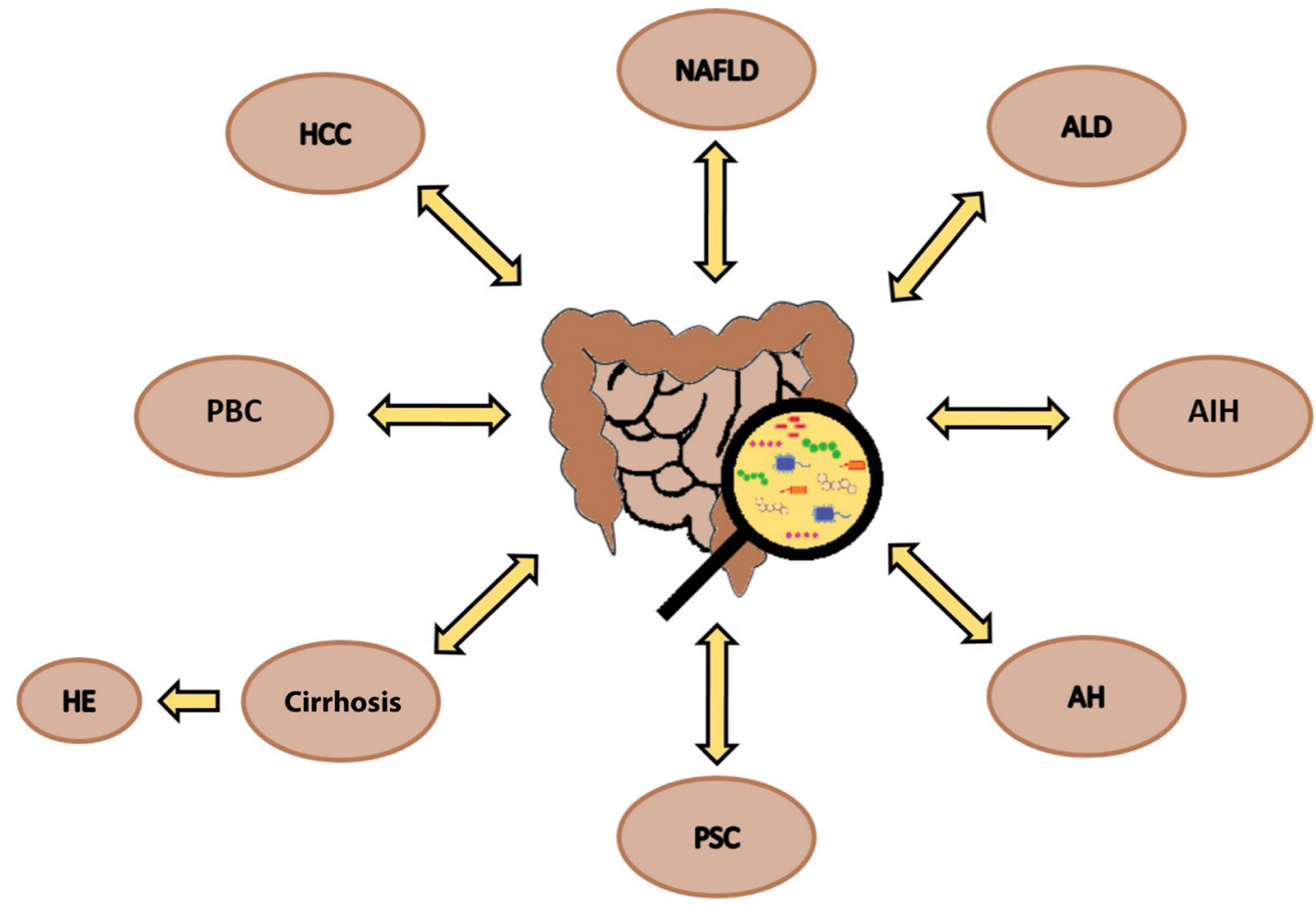

1. ábra

A bélflóra és a különböző májbetegségek kapcsolata. A kapcsolat kétirányú, hiszen nemcsak a bélflóra befolyásolja a májbetegségeket, hanem azok is módosíthatják annak összetételét, aktivitását

$\mathrm{AH}=$ alkoholos hepatitis; $\mathrm{AIH}=$ autoimmun hepatitis; $\mathrm{ALD}=$ alkoholos májbetegség; $\mathrm{HCC}=$ hepatocellularis carcinoma; $\mathrm{HE}=$ hepaticus encephalopathia; NAFLD = nem alkoholos zsírmá; $\mathrm{PBC}$ = primer biliaris cirrhosis; PSC = primer szklerotizáló cholangitis

Eddig több mint 50 bélflóraalkotó baktériumtörzset azonosítottak, ezek közül öt domináns a humán bélflórában: a Gram-pozitív Firmicutes és Actinobacteria, a Gram-negatív Bacteroidetes, a Proteobacteria és a Verrucomicrobia. A I6S rRNS-génszekvencia-alapú vizsgálatok kimutatták, hogy a Bacteroidetes- és a Firmicutesbaktériumok a distalis béltraktus mikrobiótájának több mint 90\%-át alkotják. A Bacteroideteseknek mintegy 20 nemzetsége van jelen a bélben, amelyek számos komplex glikánt bontanak. A Firmicutes pedig a legtöbb, bélflórában megjelenó nemzetséget tartalmazza, köztük a Lactobacillust, a Ruminococcust, a Clostridiumot, a Mycoplasmát és a butiráttermelő Eubacteriumot, a Faecalibacteriumot és a Roseburiát. Gyakori Proteobacterium az Enterobacteriaceae családba tartozó Escherichia, valamint a szulfátredukáló Desulfovibrio. Nemrég felfedezett törzs a Verrucomicrobiota, amelynek egyik nemzetsége, az Akkermansia a nyálkahártya mucinbontását végzi. Kisebb számban jelen lévő baktériumcsoport a Cyanobacteria, a Fusobacteria, a Lentisphaerae, a Spirochaetes és a TM7 [11].

\section{A bélflórát vizsgáló módszerek}

A bélflóra minőségét és mennyiségét vizsgáló módszereknek baktériumtenyészet-függố és az attól független formája különböztethető meg. Az előbbi technika alkal- mazása ma is igazán elterjedt az összetétel meghatározására, annak ellenére, hogy a bélflórának mindössze 30\%-a tenyészthető ki. A maradék 70\% számára igen nehéz felismerni és megteremteni az optimális tenyésztési körülményeket. A tenyésztésfüggetlen módszerek alkalmasabbak a bélflóra komplexitásának jellemzésére [4]. Kiemelkedő a kvantitatív PCR (qPCR) és a fluoreszcens in situ hibridizációs (FISH-) technika, amely alkalmas és érzékeny különböző baktériumcsoportok számszerú meghatározására. Az elmúlt években a generációs szekvenálási technikák (16S rRNS-szekvenálás, metagenomikus analízis) jelentősen fejlődtek, így egyre többet tudunk meg a bélflóra összetételéról, ismert és ismeretlen baktériumokat tudunk azonosítani; lehetőség nyílt bélflórák összetételének összehasonlítására (egészségesegészséges; egészséges-beteg; beteg-beteg), valamint olyan nem redundáns mikrobiális gének azonosítására, amelyek összefüggésbe hozhatók bizonyos betegségek progressziójával $[4,12]$.

\section{A bélflóra szerepe a májmúködésben}

Az intestinalis mikrobióta és a gazdaszervezet együttélése mindkét fél számára előnyös [5]. A bélbaktériumok szerepet játszanak a gazdaszervezet sejtjeinek energiatermelésében. Az emészthetetlen növényi poliszacharidokat rövid szénláncú zsírsavakra (SCFA) bontják, amelyek 
energiaforrást jelentenek az intestinalis epithelium számára. A butirát elsősorban a colonocyták kedvelt energiaforrása. A mikrobák által termelt butirát a portalis keringésen keresztül a májba jut, ahol csökkenti a glükózoxidációt, fokozza a glikogénszintézist és a máj glikogéntárolását, ami magyarázatot adhat az étkezésirost-fogyasztás és a jobb glükóztolerancia közötti összefüggésre [13]. A bélmikrobióta befolyásolja a bélhormonok - mint a glükagonszerú peptid-1 (GLPl) és a peptid YY (PYY) - felszabadulását, amelyek a jóllakottságot szabályozzák, javítják a glükóztoleranciát, az inzulinérzékenységet. Az SCFA-k - mint a butirát, a proprionát, az acetát - változatos szerepet töltenek be: szabályozzák a bélmotilitást, a glükózhomeosztázist és az energia-háztartást [14].

A bélflóra az immunrendszer által mediált barrierfunkciót is ellát, ellenőrizve és szabályozva a portalis keringésbe és így a májba jutó bakteriális termékeket [5]. Itt is a butirát tölt be központi szerepet: potencírozza a hősokkfehérjéket, citoprotektív hatású, elősegíti a bélsejtek proliferációját, illetve biztosítja a nyálkahártya-integritást [13]

Immunmediált hatásuk közé tartozik, hogy a megfelelő bélpermeabilitás biztosításával korlátozni tudják a patogének szisztémás keringésbe való jutását, másrészt befolyásolni képesek a bakteriális kórokozók eltávolítását a májból a Kupffer-sejtek aktiválása és/vagy a portalis-vénás antigének toleranciájának indukálása révén [5].

\section{A bélflóra szerepe a májbetegségekben}

A máj és a bél közvetlen kapcsolatban áll egymással, a portalis vénán és a biliaris traktuson keresztül [3]. Így lesz a máj az elsődleges szürője a bél felől érkezô anyagoknak, amelyek a mikroorganizmusok különböző alkotóelemei, az általuk előállított termékek (endotoxinok, lipopoliszacharidok - LPS), bakteriális metabolitok (peptidoglikánok) vagy bakteriális DNS lehetnek, amelyeket patogénasszociált molekuláris mintázatnak (pathogen associated molecular patterns - PAMP) nevezünk [5]. A bélnyálkahártya, a sejtek és a sejtkapcsoló struktúrák (tight junctionok) együttesen alkotják azt a barriert, amely a bélflóra, a máj és az egyéb szervek között képez határfelületet [4].

A PAMP (LPS, endotoxin) kötődése a máj Kupffersejtjein lévő Toll-szerû receptorhoz (TLR) már igen kis koncentrációban is aktiválja a sejtet, a mitogénaktivált proteinkináz és az NFkB aktivációján keresztül gyulladásos folyamatot indít el, a TNF $\alpha$ és az IL8 produkcióját növelve [3-5].

A gazdaszervezet genetikája is hozzájárul a bélflóra diverzitásához, aktivitásához. Az inflammasomák (multiproteinkomplexek, amelyek a két legfontosabb gyulladásos citokin, az ILlß és az ILl8 hasításáért felelős kaszpáz-1-et aktiválják) kulcsfontosságú szenzorai az exogén és endogén PAMP-oknak, DAMP-oknak. A genetikailag meghatározott, inflammasomamediált dysbi- osis a bakteriális termékek kóros felszaporodásához vezetett a portalis keringésben (TLR4-, TLR8-agonisták), aminek következtében a májelzsírosodás fokozódott [15]. Egérkísérletek során azt találták, hogy a MyD88 (myeloid differentiation primary response 88 ) gén hiánya inzulinrezisztenciára, glükózintoleranciára, valamint májelzsírosodásra hajlamosított. A gén egy központi adapter a TLR-ekhez, részt vesz az inflammasomák alkotásában és olyan epesavak, valamint bioaktív lipidek képződésszabályozásában, amelyek a glükóz-, a lipidmetabolizmus és a gyulladásos folyamatok szabályozói [16].

Az epesavaknak közvetlen hatásuk van a mikrobiótára: epeúti elzáródás dysbiosist és a nyálkahártya-barrier epesavak adásával visszafordítható sérülését idézte elő rágcsáló- és humán vizsgálatokban [17]. A mikrobióta az elsődleges epesavak másodlagossá alakításával az epesavak nukleáris receptorán, a farnezoid X-receptoron számos folyamatot befolyásol [18], például a koleszterinmetabolizmus és ezáltal az epesavak képződését. A receptoron keresztül az enteroprotekcióban részt vevő gének aktiválódnak, amelyek a bakteriális túlnövekedést és transzlokációt gátolják [3]. A farnezoidreceptor ligandjai más transzkripciós faktorokkal való kölcsönhatás révén (például aktivátor protein-1, signal transducers and activators of transcription 3) antiinflammatorikus hatást fejtenek ki [19].

\section{Nem alkoholos zsírmáj betegség}

A nem alkoholos zsírmáj betegség (NAFLD) és a steatohepatitis (NASH) kialakulása többlépcsős folyamat ( "multi hit hypothesis”), a bélflórának a NAFLD kialakulásában és progressziójában is szerepe van. Megváltozik a bélflóra összetétele, a sejtkapcsoló struktúrák (tight junction) károsodásával nő a bélpermeabilitás, a szérumendotoxin-szint emelkedik, szabad gyökök képződnek, szisztémás gyulladás ( $\mathrm{TNF} \alpha$ fokozott génexpresszió) alakul ki. Az endogén alkoholtermelés, az epesav-összetétel és a kolinmetabolizmus is módosul $[4,5]$.

A NAFLD-s betegek bélflórája összetételében megváltozik (például alacsonyabb Bacteroides-, Ruminococcaceae-, Oscillibacter-koncentráció, ugyanakkor a Firmicutes, Lactobacillus, Lachnospiraceae, Dorea, Robionsella, Roseburia, Gammaproteobacteria, Prevotella, Enterobactericeae, Escherichia növekedésével) [3]. Az epesavösszetétel megváltozásáról, nagyobb szérumepesav-koncentrációról (glikokolsav, taurokolsav) számoltak be NASH-es betegekben [20].

A kolinanyagcsere is szerepet játszhat a NAFLD kialakulásában. Állatmodelleken steatohepatitis jelent meg metionin- és kolinszegény diéta mellett. Az intestinalis bélflóra szükséges a normális kolinmetabolizmushoz, azonban a magas zsírtartalmú étrend dysbiosist okoz, s így a kolin biológiai hasznosulása csökken, kolinhiányos állapot alakulhat ki, amely NASH-t indukálhat [5]. 


\section{Alkoholos májbetegség}

$\mathrm{Az}$ alkoholos májbetegséget (ALD) a dysbiosis, a csökkent intestinalis barrierfunkció, valamint az emiatt kialakuló endotoxaemia és nagyobb lipopoliszacharidszint jellemzi [4].

A károsodott intestinalis barrier már egészen korán megjelenik, sokszor meg is előzi a dysbiosist. Az ALD-s betegek egy csoportjában a dysbiosis során a Bacteroides szintje csökkent, míg a Proteobacteriumoké és az Enterobactericeaeké nőtt [21]. A Proteobacteriumok és a Gram-negatív baktériumok számbeli növekedése egyben növelte az acetaldehidtermelést, ami a sejtkapcsoló struktúrák, tight junctionok károsítása révén fokozta a bélpermeabilitást. Emellett az alkohol közvetlen toxikus hatása is növeli az áteresztőképességet, és csökkenti az epithelialis microtubulus funkciót [5].

A bélmikrobióta néhány alkotója valószínúleg véd az alkoholos májbetegség kialakulásával szemben, csíramentes egerekben súlyosabb májkárosodás, steatosis és gyulladás alakul ki alkoholtáplálás következtében [22].

A dysbiosis, valamint az intestinalis permeabilitás az alkoholfüggőség súlyosságában is szerepet játszhat. Felvetették, hogy a bél-agy tengelynek fontos szerepe lehet, hiszen a bélflóra szabályozhatja a viselkedési rendellenességek, például az alkoholfüggőség kialakulását is [23].

Az alkoholfogyasztás a bélben jelen lévő gombák öszszetételét (mikobiom) is megváltoztatja, a gombasejtfalalkotó béta-glükán magasabb szintjét észlelték alkohol"kezelés” hatására egerekben. A béta-glükán a Kupffersejteken és más csontvelö-eredetû sejteken megtalálható C típusú lektinszerú receptoron keresztül az ILlß expresszióját fokozva hozza létre a gyulladást, valamint a májkárosodást. Amfotericin-B-kezelés a béta-glükán transzlokációját csökkentette, az alkoholos májbetegséget enyhítette. Alkoholfüggő egyénekben a gombák diverzitása csökken a bélben, a Candida speciesek túlnövekedésével $[6,24]$.

\section{Alkoholos hepatitis}

$\mathrm{Az}$ alkoholos hepatitishez $(\mathrm{AH})$ kapcsolódó dysbiosisra jellemző a bifidobaktériumok, a Streptococcusok és az Enterobacteria számának növekedése, míg a Clostridium, a Leptum vagy a Faecalibacterium prausnitzii száma csökken. Az AH átvihető széklettranszplantációval (FMT = fecal microbial transplantation) csíramentes és hagyományos egerekbe is [25]. Egerekben akkor alakult ki súlyos $\mathrm{AH}$, ha a humán donor is súlyos AH-ben szenvedett. Súlyos AH-ben nagyobb volt a bélpermeabilitás és az intestinalis mikrobióta transzlokációja is, amit a bélnyálkahártya védelméért felelős mucin (MUC2 gén) csökkent expressziójával hoztak összefüggésbe. Súlyos AH-ben az epesavak összetétele is megváltozik, csökkent az urzodeoxikólsav és a kenodeoxikólsav koncentrációja. A kenodeoxikólsavat a bélbaktériumok urzodeoxikólsavvá alakítják, ami a májsejtek antioxidáns védelmét jelenti.
A kenodeoxikólsav az alkohol-dehidrogenáz-1 mûködését is serkenti [6].

A krónikus alkoholfogyasztás csökkenti az úgynevezett antimikrobiális regeneráló REG3 (regenerating islet-derived protein 3 ) lektinek szintjét a béltraktusban. Ha a bélrendszer-specifikus REG3B vagy REG3G hiányzik, akkor növekszik a baktériumok száma, amelyek ezután a mesenterialis nyirokcsomókba transzlokálódnak, és így súlyosbodik az etanol indukálta steatohepatitis. Ezzel ellentétben, ha a REG3G túlexpresszált, az állatok védettek voltak az etanol indukálta májkárosodással szemben, ami összefüggésben állt a csökkent bakteriális kolonizációval [26].

\section{Primer szklerotizáló cholangitis}

Primer szklerotizáló cholangitisben (PSC) is csökken a bélmikrobióta diverzitása. Tizenegy fajta baktérium (Prevotella, Roseburia, Bacteroides) fordul elő kevésbé gyakran [27], mindemellett viszont az Enterococcus, a Fusobacterium, a Lachnospiraceae, a Megasphera, a Barnesiellaceae és a Lactobacillus gyakorisága nő. [3]. Hasonló dysbiosis figyelhető meg IBD-hez asszociált PSCben, amely különbözik az IBD-sek bélflórájától [3]. A kórképben a Veillonella genus gyakorisága szintén nő. A baktérium réz-amin-oxidáz fehérjéket termel, amelyek a vascularis adhéziós fehérje-1-et és a lymphocyták aberráns transzportjában részt vevő adhéziós molekulák expresszióját befolyásolhatják [28].

A transzlokált bélbaktériumok és antigének kezelését (handling) végző, az intestinalis epithelialis sejtek fukozilációját katalizáló FUT2 géntermék nagy kockázatú variánsa és az IBD-hez asszociált PSC között kapcsolatot írtak le. A baktériumok az epithelialis fukozilációt indukálják, amelyet számos baktérium táplálkozási szénhidrátként használ fel [29].

Állatmodellekben megfigyelték, hogy a genetikailag módosított, MDR2 (multidrogrezisztens-2)-hiányos egerekben a másodlagos epesavak hiányoznak, és az állatokban biokémiailag és hisztológiailag a PSC-hez hasonló májbetegség alakul ki [30].

\section{PBC és AIH}

A bélmikrobióta szerepét vizsgáló tanulmányok száma csekély PBC-ben és AIH-ben. Az autoimmunitást vélhetően környezeti tényezők indítják el molekuláris mimikri révén. A PBC-s betegek 95\%-a antimitochondrialis antitest-pozitív, ami keresztreakciót ad több bakteriális antigénnel, mint az Escherichia coli, Lactobacillus delbrueckii, Novospingobium aromaticivorans [31]. A mikrobióta megváltozását is leírták PBC-s betegekben, például a Gram-pozitív coccusok gyakoribbak voltak [32].

Autoimmun hepatitises betegekben a bifidobaktérium és a Lactobacillus előfordulása csökkent, valamint a tight junction fehérjék (occludin) csökkent expresszióját találták duodenum-nyálkahártyában, a szérumban emelkedett lipopoliszacharidszinttel [33]. 


\section{Májcirrhosis}

A májcirrhosis a fejlett országokban is gyakori oka a morbiditásnak és mortalitásnak. A cirrhosis elsődleges kockázati tényezői az alkoholfogyasztás, a krónikus HCV- és HBV-fertőzés, a NAFLD, az immunalapú megbetegedések, valamint a tárolási kórképek [34].

A széklet mikrobiális összetételének megváltozásáról számoltak be cirrhosisban: a Bacteroidesek száma jelentősen csökkent, míg a Proteobacteriumok és a Fusobacteriumok száma szignifikánsan emelkedett. A betegség fenotípusát és prognózisát befolyásolja az Enterobacteriaceae és a Streptococcaceae baktériumok gyakoribb, valamint a Lachnospiraceaek ritkább elófordulása [4]. Cirrhoticus betegek dysbiosisa 54\%-ban buccalis eredetü volt, ami a szájüregi flóra megjelenését bizonyítja az alsóbb bélszakaszokban - ez szintén befolyásolhatja a betegség lefolyását és prognózisát [35]. Állatmodellben streptozotocin-magas zsírtartalmú étrend okozta steatosis, fibrosis, végül pedig HCC kialakulása során számos baktériumfaj (Bacteroides, Atopobium spp, Clostridium cocleatum, Clostridium xylanolyticum, Desulfovibrio) száma nőtt, amelyek megjelenése korrelált az endotoxaemiával és a klinikai képpel [36].

\section{Hepaticus encephalopathia}

Nemcsak az előrehaladott májbetegséget és a dekompenzációt határozza meg a dysbiosis, hanem annak jellemző szövődményeit is, mint például a hepaticus encephalopathia (HE) kialakulása.

Az agy és a bél mikrobiótája közötti kapcsolat kétirányú, a neuronalis, az endokrin és az immunmediált kommunikáció bizonyított. Az agyat elérő információ menynyiségét és típusát befolyásolja: a regionális intestinalis környezet - mucusszekréció, az antimikrobiális peptidek előállítása, az intraluminalis noradrenalin kiáramlása -, a belek epithelialis barrierjének és a vér-agy gátnak a permeabilitása, a bélflóra metabolitjainak májon keresztüli clearence-e [4].

A cirrhosisos HE-s betegeknél magasabb volt a Staphylococcusok, az Enterococcusok, a Porphyromonasok és a Lactobacillusok szintje a székletben, mint a nem HE-s cirrhoticusoknál, illetve az egészségeseknél. A cirrhosisos HE-s betegek endotoxintermelése, endotoxin-protein szintézise is megváltozik. A fiziológiás mikrobióta véd, az Enterobacteriaceae pozitívan korrelált a magasabb ammóniaszint indukálta astrocytaváltozásokkal [4].

\section{Ammónia}

Az elmúlt 100 évben a megnövekedett ammóniaszint és annak agyra kifejtett toxikus hatásai voltak a legszélesebb körben elfogadott magyarázó tényezők a hepaticus encephalopathia kialakulásában [4]. Elfogadott tény, hogy a bélflóra az ammóniatermelés fó forrása, hiszen a gluta- min-anyagcsere során a baktériumok termelik, ugyanakkor egyre több bizonyíték áll rendelkezésre, miszerint a zsigerekból (vékonybél, vesék) is származhat valamely glutamináz izoforma (L-PAG/K-PAG) múködése révén [37]. Az ammónia a karbamidciklusban bomlik le, ez azonban cirrhosisban károsodik, sőt a glutamin $\rightarrow$ glutamát átalakulás mint ammóniatermelést csökkentő folyamat is zavart szenved. Az ammónia emelkedett szintjéhez a portalis ammóniaclearance károsodása, az astrocyták fokozott ammóniafelvétele is hozzájárul [5].

\section{$G A B A$}

Kísérleti modellek múködési zavart igazoltak a szerotonin-, a GABA- és a katecholaminmetabolizmusban is [5]: növekszik a GABAerg tónus az agy egyes területein, károsodik az intestinalis barrierfunkció, és jelen van egy alacsony szintű szisztémás gyulladás, neuroinflammatio és bélflóra-módosulás [4].

\section{Indol}

Az aminosavak metabolizmusából keletkező termékek, mint például a triptofán, olyan vegyületek keletkezéséhez vezethetnek (indol), amelyekből oxindol jöhet létre. A HE-s betegek indolszintje jelentősen magasabb mind az egészséges kontrollhoz, mind a HE nélküli, illetve a minimálisan HE-s cirrhosisos betegekhez képest. A cirrhoticus betegek oxindolszintje szintén növekedett. Pozitív kapcsolatot mutattak ki az ammónia, az oxindol/indol szintek és a HE-ben jellemző EEG-elváltozások között [38].

\section{Hepatocellularis carcinoma}

A hepatocellullaris carcinoma (HCC) mikrobiótával való kapcsolata nem tisztázott, mert az erre irányuló vizsgálatokból egymásnak ellentmondó eredmények születtek.

Valószínú, hogy a gyulladásos útvonal aktiválódása a TLR-stimuláció által növeli a daganat kialakulásának kockázatát [5] (2. ábra).

\section{A mikrobióta mint kezelési lehetőség májbetegségben}

Az egészséges mikrobiom helyreállítására („rebiosis”) való törekvés mint az idült májbetegségek kezelési lehetősége, kutatások tárgya [4-6].

\section{Táplálkozás}

A táplálkozás a bélmikrobiótát befolyásolja, s így májbetegségek kialakulására is hatása lehet.

A nagy zsírtartalmú diéta a kalóriamegszorítástól függetlenül nagyobb LPS-szintet okozott állatokban. A kalóriamegszorítás nélküli zsírbevitel a Firmicutesek szá- 


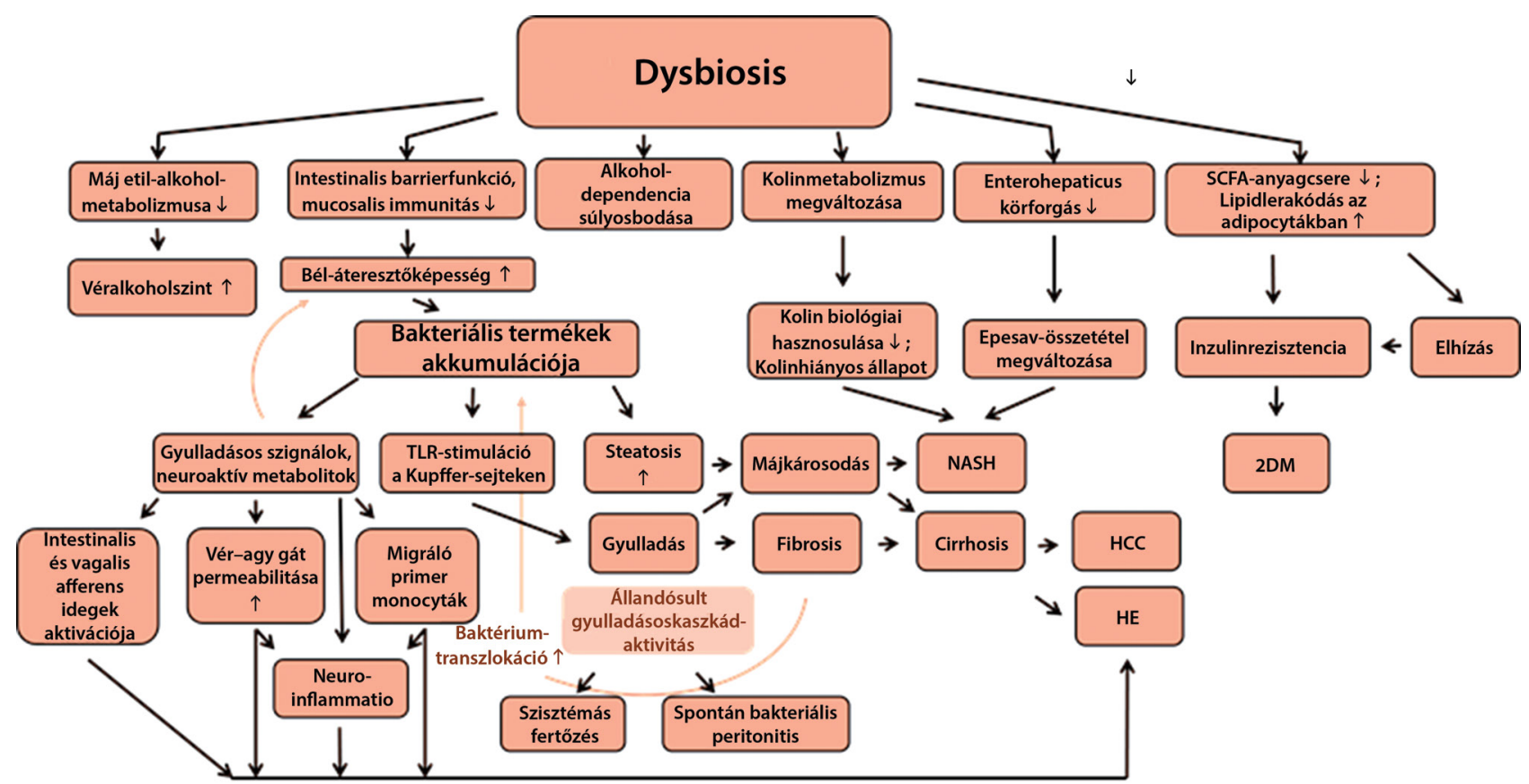

2. ábra

\begin{abstract}
A dysbiosis hatásai a szervezetre és a következményes megbetegedések. A megváltozott bélflóra több útvonalon keresztül járulhat hozzá a különböző betegségek, szövődmények kialakulásához, progressziójához

$2 \mathrm{DM}=2$-es típusú cukorbetegség; HCC $=$ hepatocellularis carcinoma; HE $=$ hepaticus encephalopathia; $\mathrm{NASH}=$ nem alkoholos steatohepatitis; SCFA = rövid szénláncú zsírsavak; TLR = Toll-szerú receptor
\end{abstract}

mát növelte a Bacteroidesek számának csökkenésével, míg az izokalóriás zsírbevitel csak a Firmicutesek számát emelte. A magas szénhidrát- és fehérjebevitel hatása ellentétes volt, a Bacteroidesek gyakoribbak voltak, míg a Firmicutesek száma csökkent. A nagy zsír- és szénhidrátbevitel a kalóriabeviteltól függetlenül segítheti a NAFLD kialakulását, és más módon befolyásolja a bélflóra-összetételt. A nagy fehérjetartalmú táplálkozás jótékony hatása a Prevotella és az Oscillospira számának növekedésére vezethető vissza [39].

Telítetlen zsírsavak bevitele a Bacteriodetesek számát csökkentette, míg a Proteobacteriumok és Actinobacteriumok számát növelte, és súlyosabb, alkohol okozta endotoxinaemiát, májelzsírosodást és károsodást idézett elő [40].

A kolinhiány reverzíbilis májelzsírosodást okoz. A bélbaktériumok a kolint metil-aminná alakítják, aminek nemcsak a kolinkoncentráció csökkenése a következménye, hanem a metil-amin önmaga is toxikus és gyulladást keltő. A Gammaproteobacteriumok a kolinhiány okozta májelzsírosodás kialakulásával szemben nyújtanak védelmet nőkben [41].

\section{Antibiotikumok}

A kolinmentes diétán tartott patkányokban a neomicin bevezetése védelmet jelentett a fibrosis és a cirrhosis kialakulásával szemben, ami az endotoxintermelés korlátozására vezethető vissza [5].
Orális vankomicinkezelés a PSC-ben szenvedő betegek biokémiai paramétereit javította, vélhetően a bélmikrobióta befolyásolásával [30].

A HE kezelésében is felmerült a neomicin alkalmazásának lehetősége, ugyanis a mucosalis glutamináz enzim gátlása révén csökkenti az ammóniaképződést [5]. A vankomicin, a neomicin és a metronidazol oto-, nefroés neurotoxikus hatása korlátozza hosszú távú alkalmazásukat [6].

A nem felszívódódó, széles spektrumú antibiotikumok az ammóniatermelő bélbaktériumok mennyiségét csökkentik. A rifaximint számos vizsgálatban hasonlították össze placebóval, nem felszívódó diszacharidokkal és más antibiotikumokkal, ekvivalensnek vagy jobbnak és tolerálhatónak bizonyult. A tünetekkel járó hepaticus encephalopathiában, illetve a második epizód megelőzésére a laktulóz kiegészítéseként jön szóba [5, 42]. Ugyanakkor cirrhosisos betegek bélflórájában a Veillonellaceae $2 \%$-os csökkenésén (4\%-ról $2 \%$ ) és az Eubacteriaceae 2\%-os növekedésén (0\%-ról 2\%) kívül nem eredményezett változást a rifaximinkezelés [43]. Az emelkedett endotoxinszintre is számos bizonyíték van, amely a mikrobióta metabolikus funkciójának megváltozásán alapszik, mintsem a flóra összetételének módosulásán. A rifaximin a telített és telítetlen zsírsavak szintjét emelte a szérumban. Az arachidonsav és a linolénsav emelkedett szintjének jótékony hatása lehet az agyi funkcióra [6].

Míg a HE-s májbetegek körében igazolt a rifaximin hatásossága, addig a nem cirrhosisos, krónikus májbeteg- 
ségekben betöltött szerepe még kevésbé bizonyos. NASH-os betegeknél a BMI, a szérumendotoxin, a GOT, a GPT és a GGT csökkent rifaximinkezelés hatására, míg a NAFLD-es betegeknél csupán a GPT csökkenését tapasztalták [44].

\section{Prebiotikumok}

A májbetegségek kezelésének egy másik alternatívája a nem emészthető táplálékok, prebiotikumok alkalmazása, amelyek hatása a bélflóra stimulációján alapszik.

HE ismételt előfordulásának megelőzésére alkalmas a nem felszívódó szénhidrát, a laktulóz, amelynek hatásmechanizmusa nem teljesen tisztázott, de úgy vélik, a laktulóz a bélflóra módosításával megkönnyíti az ammónia kiválasztását [5]. Azt is kimutatták, hogy HE-ban a laktulóz megvonása indirekt módon emeli a glicinkoncentrációt, ami részben a Faecalibacterium számának csökkenésére vezethető vissza [45].

Fruktánokban gazdag táplálékkal etetett patkányokban javult a postprandialis inzulin- és glükózkoncentráció, csökkent a lipogén enzimek génexpressziója, és így csökkent a triacil-glicerid-szint a VLDL-ben, javult a lipidanyagcsere. Humán vizsgálatokban a fokozott fruktánbevitel a szérum-triacil-glicerid-szintet csökkentette [6]. A fruktán típusú oligofruktóz adására 4 hét után az inzulinszint, 8 hét után pedig az aminotranszferázok aktivitása szignifikánsan csökkent NASH-os betegekben [46].

Kimutatták, hogy a bélflóra összetételének prebiotikummal (inulin típusú fruktán) történő megváltoztatása csökkenti a májzsírosodást és a de novo lipogenezist [4].

Prebiotikummal táplált patkányokban a szérumtriglicerid- és VLDL (very-low-density lipoprotein)-szint csökkent, hiszen a prebiotikumok gátolják a lipogén enzimeket: acetil-CoA-karboxiláz (ACC), malát-dehidrogenáz, ATP-citrát-liáz és glükóz-6-foszfát-dehidrogenáz (G6PD). A prebiotikumok fermentációja megemeli az SCFA-k mennyiségét mind a bélben, mind a portalis keringésben, s így az acetát és a proprionát szintje is megkétszereződik, amelyek közül az utóbbi csökkenti a máj lipogenezisét, az előbbi pedig a lipogenezis szubsztrátja [4].

A prebiotikumok hatásait vizsgáló tanulmányok hiányoznak.

\section{Probiotikumok}

A probiotikumok terápiás jelentőségét mind humán vizsgálatokban, mind állatkísérletekben vizsgálták. Több tanulmány alátámasztotta a Lactobacillus jótékony hatásait: a gyulladásos kaszkád és az endotoxaemia csökkentése. A bifidobaktérium nemcsak csökkenti a gyulladásos markerek szintjét májbetegségben, hanem mérsékli a májzsírosodást, és javítja a glükóztoleranciát is [5].
A májbetegségek közül a NAFLD probiotikummal való összefüggéseit vizsgálták a legszélesebb körben. Lactobacillus, illetve Lactobacillus és Streptococcus adása az aminotranszferázok szintjét csökkentette NAFLDben [47]. Az állatkísérletekkel ellentétben a bifidobaktériumról kimutatták, hogy humán alkalmazás esetén csak akkor fejti ki endotoxaemia- és steatosismérséklő hatását, ha fruktooligoszacharidokkal kombinálják. A szimbiotikumkezelésben (Bifidobacterium longum és prebiotikum) részesülő csoportban 24 hét után csökkent a gyulladásos markerek szintje, valamint a steatosis és a NASH aktivitási indexe [5].

Alkoholos májbetegeken végzett vizsgálatok azt mutatták, hogy a Lactobacillus- és a bifidobaktériumkezelés kismértékben csökkentette a transzamináz-aktivitást, csökkent az endotoxinszint, az immunválasz és az oxidatív stressz. A csökkent immunválaszt magyarázza, hogy a kiinduláskor csökkent neutrofilfagocita-kapacitás normalizálódott, az ex vivo endotoxinnal stimulált sTNFRl, az sTNFR2 és az IL10 szintjei alacsonyabbak voltak, a túlexpresszált TLR4 kifejeződése normalizálódott. Az oxidatív stressz csökkenésének oka a két baktérium lipidperoxidációt gátló, 4NQO-citotoxicitás-csökkentő és DPPH-szabadgyökfogó hatása [48].

Metaanalízis igazolta a probiotikumok hatékonyságát minimál- és klinikai hepaticus encephalopathiában. Rutinszerü alkalmazásuk megítélésére további randomizáltkontrollált vizsgálatok szükségesek [6, 42].

246 esetet feldolgozó 4 kontrollált vizsgálat metaanalízise alapján a prebiotikumok és a probiotikumok kombinált alkalmazása jelentősen csökkenti a fertőzések és a szükséges hospitalizációk számát azoknál a májátülttetett betegeknél, akiknél ezt a mútét napján vagy azt megelőzően alkalmazták. A kórházi vagy intenzív osztályon eltöltött idő és az antibiotikumhasználat időtartama is rövidült [49].

\section{Széklettranszplantáció}

A széklettranszplantáció alkalmazása elsősorban a Clostridium difficile-fertózés kezelésében terjedt el, egyéb gastrointestinalis kórképekben, mint lehetséges kezelési módszer, vizsgálatok tárgya. Jelenleg nincs randomizált, kontrollált tanulmány, amely a széklettranszplantációt vizsgálta májbetegségekben. Az eddigi tapasztalatok állatkísérleteken, valamint klinikai megfigyeléseken alapulnak.

Humán vizsgálatok csekély számban állnak rendelkezésünkre, de az inzulinérzékenység javulást mutatott azokban az elhízott egyénekben, akikbe sovány egyének székletét transzplantálták [50].

A széklettranszplantációnak mint a májbetegségek lehetséges terápiájának igazolásához további vizsgálatok szükségesek. Jelenleg NAFLD-ben, PSC-ben és rekurrens hepaticus encephalopathiában vizsgálják a széklettranszplantációt. 


\section{Következtetés}

A bél mikrobiótája jelentős szerepet tölt be a máj fiziológiás és patológiás folyamataiban, amelynek kutatása kiemelkedő, új kutatási terület. Elsősorban preklinikai kutatások vetették fel, hogy a bélflóra szerepet játszhat számos májbetegség kialakulásában (steatosis, májgyulladás, fibrosis, HE). További tanulmányok pedig megerősítették a megváltozott, „diszfunkcionális” bélflóra szerepét a nem alkoholos zsírmáj betegség, az alkoholos májbetegség, valamint a primer szklerotizáló cholangitis kialakulásában. Májbetegségben a dysbiosisnak és a patogén baktériumoknak, valamint a vékonybél-baktériumok túlnövekedésének kiemelt szerepe van. A megváltozott bélpermeabilitás, a bakteriális transzlokáció, valamint az endotoxinaemia a portalis keringésben az immunrendszer aktiválódásához, májkárosodáshoz és szisztémás gyulladáshoz vezet. Ugyanakkor további vizsgálatok szükségesek, amelyek alátámasztják az eddigi eredményeket, valamint meghatározzák, mely baktériumok befolyásolják az adott betegség megjelenését, súlyosságát, lefolyását.

Fontos lenne szélesebb körben vizsgálni, hogyan lehet a mikrobiótát új prebiotikumokkal, probiotikumokkal, antibiotikumokkal és FMT alkalmazásával manipulálni, hiszen ezek mind szerepet játszanak, játszhatnak a májbetegségek kezelésében, megelőzésében a rebiosis által, de az alkalmazás módja, időtartama, eredményességének időtartama további vizsgálatokat igényel.

Anyagi támogatás: A közlemény megírása anyagi támogatásban nem részesült.

Szerzői munkamegosztás: H. K.: Témafelvetés, irodalomkutatás, a kézirat megírása, szerkesztése. B. A.: Irodalomkutatás, a kézirat megírása, szerkesztése. E. A.: A kézirat szerkesztése, szakértői részvétel a problémafelvetésben. B. E.: Részvétel a kézirat végleges formájának kialakításában. T. Zs.: Témafelvetés, a kézirat áttekintése. L. G.: Témafelvetés, szakértői részvétel a problémafelvetésben. A cikk végleges változatát valamennyi szerző elolvasta és jóváhagyta.

Érdekeltségek: A szerzőknek nincsenek érdekeltségeik.

\section{Irodalom}

[1] Sender R, Fuchs S, Milo R. Are we really vastly outnumbered? Revisiting the ratio of bacterial to host cells in humans. Cell 2016; 164: 337-340.

[2] Marietta E, Rishi A, Taneja V. Immunogenetic control of the intestinal microbiota. Immunology 2015; 145: 313-322.

[3] Pallen MJ, Quraishi MN. The gut microbiota and the hepatologist: will our bugs prove to be the missing link? Dig Dis. 2017; 35: 377-383.

[4] Tilg H, Cani PD, Mayer EA. Gut microbiome and liver diseases. Gut 2016; 65: 2035-2044.

[5] Haque TR, Barritt AS. Intestinal microbiota in liver disease. Best Pract Res Clin Gastroenterol. 2016; 30: 133-142.
[6] Woodhouse CA, Patel VC, Singanayagam A, et al. Review article: the gut microbiome as a therapeutic target in the pathogenesis and treatment of chronic liver disease. Aliment Pharmacol Ther. 2018; 47: 192-202.

[7] Halmos T, Suba I. Physiological patterns of intestinal microbiota. The role of dysbacteriosis in obesity, insulin resistance, diabetes and metabolic syndrome. [A bélbakterióta élettani jellemzői és a dysbacteriosis szerepe az elhízásban, inzulinrezisztenciában, diabetesben és metabolikus szindrómában.] Orv Hetil. 2016; 157: 13-22. [Hungarian]

[8] Barna I, Nyúl D, Szentes T, et al. Review of the relation between gut microbiome, metabolic disease and hypertension. [A bélmikrobiom, a metabolikus betegségek és a hypertonia kapcsolatának irodalmi áttekintése.] Orv Hetil. 2018; 159: 346-351. [Hungarian]

[9] D'Aversa F, Tortora A, Ianiro G, et al. Gut microbiota and metabolic syndrome. Intern Emerg Med. 2013; 8(Suppl 1): S11S15.

[10] Scarpellini E, Campanale M, Leone D, et al. Gut microbiota and obesity. Intern Emerg Med. 2010; 5(Suppl 1): S53-S56.

[11] Tremaroli V, Bäckhed F. Functional interactions between the gut microbiota and host metabolism. Nature 2012; 489: 242-249.

[12] Blottière HM, de Vos WM, Ehrlich SD, et al. Human intestinal metagenomics: state of the art and future. Curr Opin Microbiol. 2013; 16: 232-239.

[13] Guilloteau P, Martin L, Eeckhaut V, et al. From the gut to the peripheral tissues: the multiple effects of butyrate. Nutr Res Rev. 2010; 23: 366-384.

[14] Cani PD, Everard A, Duparc T. Gut microbiota, enteroendocrine functions and metabolism. Curr Opin Pharmacol. 2013; 13: 935-940.

[15] Henao-Mejia J, Elinav E, Jin C, et al. Inflammasome-mediated dysbiosis regulates progression of NAFLD and obesity. Nature 2012; 482: 179-185.

[16] Duparc T, Plovier H, Marrachelli VG, et al. Hepatocyte MyD88 affects bile acids, gut microbiota and metabolome contributing to regulate glucose and lipid metabolism. Gut 2017; 66: 620632.

[17] White JS, Hoper M, Parks RW, et al. Patterns of bacterial translocation in experimental biliary obstruction. J Surg Res. 2006; 132: $80-84$.

[18] Sayin SI, Wahlström A, Felin J, et al. Gut microbiota regulates bile acid metabolism by reducing the levels of tauro-beta-muricholic acid, a naturally occurring FXR antagonist. Cell Metab. 2013; 17: 225-235.

[19] Ding L, Yang L, Wang Z, et al. Bile acid nuclear receptor FXR and digestive system diseases. Acta Pharm Sin B 2015; 5: 135144.

[20] Ferslew BC, Xie G, Johnston CK, et al. Altered bile acid metabolome in patients with nonalcoholic steatohepatitis. Dig Dis Sci. 2015; 60: 3318-3328.

[21] Mutlu EA, Gillevet PM, Rangwala H, et al. Colonic microbiome is altered in alcoholism. Am J Physiol Gastrointest Liver Physiol. 2012; 302: G966-G978.

[22] Chen P, Miyamoto Y, Mazagova M, et al. Microbiota protects mice against acute alcohol-induced liver injury. Alcohol Clin Exp Res. 2015; 39: 2313-2323.

[23] Leclercq S, Matamoros S, Cani PD, et al. Intestinal permeability, gut-bacterial dysbiosis, and behavioral markers of alcohol-dependence severity. Proc Natl Acad Sci USA 2014; 111 : E4485E4493.

[24] Yang AM, Inamine $\mathrm{T}$, Hochrath $\mathrm{K}$, et al. Intestinal fungi contribute to development of alcoholic liver disease. J Clin Invest. 2017; 127: 2829-2841.

[25] Llopis M, Cassard AM, Wrzosek L, et al. Intestinal microbiota contributes to individual susceptibility to alcoholic liver disease. Gut 2016; 65: 830-839. 
[26] Wang L, Fouts DE, Stärkel P, et al. Intestinal REG3 lectins protect against alcoholic steatohepatitis by reducing mucosa-associated microbiota and preventing bacterial translocation. Cell Host Microbe 2016; 19: 227-239.

[27] Kummen M, Holm K, Anmarkrud JA, et al. The gut microbial profile in patients with primary sclerosing cholangitis is distinct from patients with ulcerative colitis without biliary disease and healthy controls. Gut 2017; 66: 611-619.

[28] Trivedi PJ, Adams DH. Gut-liver immunity. J Hepatol. 2016; 64: 1187-1189

[29] Goto Y, Obata T, Kunisawa J, et al. Innate lymphoid cells regulate intestinal epithelial cell glycosylation. Science 2014; 345: 1254009.

[30] Tabibian JH, O'Hara SP, Trussoni CE, et al. Absence of the intestinal microbiota exacerbates hepatobiliary disease in a murine model of primary sclerosing cholangitis. Hepatology 2016; 63: 185-196.

[31] Bogdanos D-P, Baum H, Okamoto M, et al. Primary biliary cirrhosis is characterized by IgG3 antibodies cross-reactive with the major mitochondrial autoepitope and its Lactobacillus mimic. Hepatology 2005; 42: 458-465.

[32] Hiramatsu K, Harada K, Tsuneyama K, et al. Amplification and sequence analysis of partial bacterial $16 \mathrm{~S}$ ribosomal RNA gene in gallbladder bile from patients with primary biliary cirrhosis. J Hepatol. 2000; 33: 9-18.

[33] Lin R, Zhou L, Zhang J, et al. Abnormal intestinal permeability and microbiota in patients with autoimmune hepatitis. Int J Clin Exp Pathol. 2015; 8: 5153-5160.

[34] Zhou WC, Zhang QB, Qiao L. Pathogenesis of liver cirrhosis. World J Gastroenterol. 2014; 20: 7312-7324.

[35] Qin N, Yang F, Li A, et al. Alterations of the human gut microbiome in liver cirrhosis. Nature 2014; 513: 59-64.

[36] Xie G, Wang X, Liu P, et al. Distinctly altered gut microbiota in the progression of liver disease. Oncotarget 2016; 7: 1935519366.

[37] Romero-Gómez M, Jover M, Galán JJ, et al. Gut ammonia production and its modulation. Metab Brain Dis. 2009; 24: 147157.

[38] Montagnese S, Biancardi A, Schiff S, et al. Different biochemical correlates for different neuropsychiatric abnormalities in patients with cirrhosis. Hepatology 2011; 53: 558-566.

[39] Liu JP, Zou WL, Chen SJ, et al. Effects of different diets on intestinal microbiota and nonalcoholic fatty liver disease development. World J Gastroenterol. 2016; 22: 7353-7364.

[40] Kirpich IA, Petrosino J, Ajami N, et al. Saturated and unsaturated dietary fats differentially modulate ethanol-induced changes in gut microbiome and metabolome in a mouse model of alcoholic liver disease. Am J Pathol. 2016; 186: 765-776.
[41] Spencer MD, Hamp TJ, Reid RW, et al. Association between composition of the human gastrointestinal microbiome and development of fatty liver with choline deficiency. Gastroenterology $2011 ; 140$ : 976-986.

[42] Vilstrup H, Amodio P, Bajaj J, et al. Hepatic encephalopathy in chronic liver disease: 2014 Practice Guideline by the American Association for the Study of Liver Diseases and the European Association for the Study of the Liver. Hepatology 2014; 60: 715-735.

[43] Bajaj JS, Heuman DM, Sanyal AJ, et al. Modulation of the metabiome by rifaximin in patients with cirrhosis and minimal hepatic encephalopathy. PloS ONE 2013; 8: e60042.

[44] Gangarapu V, Ince AT, Baysal B, et al. Efficacy of rifaximin on circulating endotoxins and cytokines in patients with nonalcoholic fatty liver disease. Eur J Gastroenterol Hepatol. 2015; 27: 840-845.

[45] Bajaj JS, Gillevet PM, Patel NR, et al. A longitudinal systems biology analysis of lactulose withdrawal in hepatic encephalopathy. Metab Brain Dis. 2012; 27: 205-215.

[46] Daubioul CA, Horsmans Y, Lambert P, et al. Effects of oligofructose on glucose and lipid metabolism in patients with nonalcoholic steatohepatitis: results of a pilot study. Eur J Clin Nutr. 2005; 59: 723-726.

[47] Aller R, De Luis DA, Izaola O, et al. Effect of a probiotic on liver aminotransferases in nonalcoholic fatty liver disease patients: a double blind randomized clinical trial. Eur Rev Med Pharmacol Sci. 2011; 15: 1090-1095.

[48] Stadlbauer V, Mookerjee RP, Hodges S, et al. Effect of probiotic treatment on deranged neutrophil function and cytokine responses in patients with compensated alcoholic cirrhosis. J Hepatol. 2008; 48: 945-951.

[49] Sawas T, Al Halabi S, Hernaez R, et al. Patients receiving prebiotics and probiotics before liver transplantation develop fewer infections than controls: a systematic review and meta-analysis. Clin Gastroenterol Hepatol. 2015; 13: 1567-1574.e3

[50] Vrieze A, Van Nood E, Holleman F, et al. Transfer of intestinal microbiota from lean donors increases insulin sensitivity in individuals with metabolic syndrome. Gastroenterology 2012; 143: 913-916.e7

(Hagymási Krisztina dr., Budapest, Szentkirályi u. 46., 1088 e-mail: hagymasi.krisztina@med.semmelweis-univ.hu)

\section{„Etiam veros dolores mitigat tempus." (Quintilianus)}

A cikk a Creative Commons Attribution-NonCommercial 4.0 International License (https://creativecommons.org/licenses/by-nc/4.0) feltételei szerint publikált Open Access közlemény, melynek szellemében a cikk nem kereskedelmi célból bármilyen médiumban szabadon felhasználható, megosztható és újraközölhető, feltéve, hogy az eredeti szerző és a közlés helye, illetve a CC License linkje és az esetlegesen végrehajtott módositások feltüntetésre kerülnek. 